\title{
Review
}

Neuro epidemiology

\section{Stroke Knowledge in Spanish-Speaking Populations}

\author{
Maximiliano A. Hawkes ${ }^{a}$ Sebastián F. Ameriso ${ }^{a} \quad$ Joshua Z. Willey ${ }^{b}$ \\ ${ }^{a}$ Neurology Department, Institute for Neurological Research FLENI, Buenos Aires, Argentina; ${ }^{\text {b } D e p a r t m e n t ~ o f ~}$ \\ Neurology, Columbia University, New York, N.Y., USA
}

\section{Key Words}

Stroke knowledge · Stroke literacy · Spanish-speakers . Spain · Latin America

\begin{abstract}
Background: Spanish is the second most-spoken language in the world. Spanish-speaking populations (SSP) have heterogeneous cultural backgrounds, racial and ethnical origins, economic status, and access to health care systems. There are no published reviews about stroke knowledge in SSP. We reviewed the existing literature addressing stroke knowledge among SSP and propose here some future directions for research. Summary: We identified 18 suitable studies by searching PubMed, Lilacs, Scopus, Embase, Cochrane and Scielo databases, and by looking at reference lists of eligible articles. We also included 2 conference abstracts. Data related to stroke knowledge from studies of Spanish-speakers were analyzed. Key Messages: Little is known about stroke knowledge in SSP, especially in Latin America. Information is lacking even among subjects at risk, stroke patients, stroke survivors, and health care providers. 'Ictus', the word used for stroke in Spanish, is largely unrecognized among subjects at risk. Furthermore, access to medical care and the availability of neurologists are suboptimal in many regions. There are several potential issues to solve regarding stroke knowledge and stroke care in SSP. Programs to educate the general population and non-neurologists medical providers in stroke and telemedicine may be better ways of improving the present situation.

(c) 2015 S. Karger AG, Basel
\end{abstract}

\section{Introduction}

Stroke is the second leading cause of mortality and the third leading cause of disability-adjusted life years $[1,2]$. Intravenous tissue plasminogen activator (IV rt-PA) is highly effective at reducing disability and improving outcomes $[3,4]$. Even though IV rt-PA utilization rates are increasing $[5,6]$, the overall utilization rates are far from optimal. The principal cause of non-use of IV rt-PA is delayed arrival time to the hospital [7]. These delays are mainly associated with the recognition of stroke symptoms and activation of Emergency Medical Systems (EMS) [8-12].

Stroke awareness is poor among the general population [13-15] and the post-stroke patients [16] worldwide, though little is known about populations outside of North America and Europe, especially among Spanish speakers. This is of concern given that Spanish is the second most frequently spoken language in the world $[17,18]$, and Spanish speakers from developing countries represent an important source of immigrants to non-Spanish-speaking countries.

In the United States of America for example, Hispanics are the largest and fastest growing minority $[19,20]$ and appear to have a particularly high unawareness of stroke knowledge, along with lower chances to receive IV rt-PA treatment $[21,22]$. Spanish-speaking Hispanics (SSH) have been found to have a higher prevalence of cardiovascular risk factors, greater barriers to care, and reduced quality and health outcomes than English-speak-

\section{KARGER 125}

( 2015 S. Karger AG, Base

$0251-5350 / 15 / 0443-0121 \$ 39.50 / 0$ 
ing Hispanics (EEH) $[20,23]$. EEH women in one study were significantly less likely to correctly identify stroke symptoms than non-Hispanic whites [24]. Lower stroke knowledge among EEH and SSH suggests a cultural barrier in stroke awareness, which extends beyond language [25].

One potential barrier to stroke knowledge is the terminology used to describe the disease. 'Ictus' is the Spanish word of stroke. However 'ictus' is not widely recognized as a stroke equivalent among Spanish speakers [26-31].

It is important to know the current status of knowledge that Spanish speakers, located in different countries, have about stroke. As cerebrovascular disease is highly prevalent in Spanish-speaking countries and is a major public health problem, this information will be vital for the current health authorities to start tailored education programs for the general population. The purpose of this review is to summarize the literature regarding stroke knowledge among Spanish-speaking populations (SSPs) and propose future directions for research.

\section{Search Strategy}

Studies were identified by searching PubMed, Lilacs, Scopus, Embase, Cochrane and Scielo databases (Appendix 1). No limits were applied. Additional data was found by scanning reference lists of eligible articles. Search filters were constructed for (1) stroke knowledge and (2) Spanish-speaking population (Appendix 2).

\section{Selection Criteria}

The inclusion criteria were: (1) studies about stroke knowledge: word to call stroke, damaged organ, risk factors (RF), etiology, warning signs (WS), treatment and intention to call EMS, (2) articles in English and Spanish. In case additional data was required we contacted authors.

\section{Stroke Knowledge among Spanish Speakers}

We found 18 articles addressing stroke knowledge among Spanish speakers. Only three were related to Latin American populations: Colombia and Mexico. Of the remainder, 11 originated from Spain, and 4 from SSH living in the United States. We included two conference abstracts from Argentina [32, 33].

The lack of sufficient published data in Latin America is of concern and it is not clear what the reasons behind it may be. The absence of IV rt-PA availability in many Latin American regions may be a reason for underreporting. As rapid arrival in those countries is unlikely to lead to acute stroke treatment, there is less of an impetus to understand delays to hospital arrival. Economic, cultural and access to health resources make extrapolation of data from the United States and Spain to Latin America suboptimal.

The terminology used to refer to stroke in Spanish was an interesting finding, with different terms used among patients. All studies exploring this topic were done in Spain (table 2). Two studies found that 3.9 and $10 \%$ of individuals could not identify a single term for stroke [26, 29]. No patients knew the term 'ictus' in two studies [26, 28 ] and it was largely unrecognized in additional reports $[29,30]$. In several studies, 'embolia' (embolism) appears to be the term most frequently recognized [26]. The term 'ataque isquémico transitorio' (transient ischemic attack) is largely unrecognized [26]. This is of particular concern given that many strokes after TIA may be prevented by early recognition and treatment $[34,35]$.

We found significant differences in studies regarding stroke knowledge according to whether they were performed among the general population or among patients with stroke. We find this difference important since the first one provides information about 'theoretical knowledge' and the latter one about the 'practical knowledge', that is, what patients actually did.

\section{Stroke Knowledge among the General Population}

Table 1 shows the great heterogeneity across published studies making comparison between populations difficult.

\section{Educational Level}

Most studies found that $>50 \%$ of individuals had completed elementary school or lower educational standards $[26,29]$. SSH in the United States had low literacy rates in several studies. In the Behavioral Risk Factor Surveillance System Survey study (BRFSS), $51 \%$ of SSH had less than high school education compared with $14 \%$ of EEH [23]. An additional study showed that most SSH were functioning at the beginning level after testing literacy using the Basic English Skills test. This was noticed as sudden trouble walking, dizziness or loss of balance were significant less recognized as stroke symptoms among lower literacy groups [37].

\section{Brain Affected in Stroke}

Hispanics in Central Harlem were less likely to recognize brain as the damaged organ in stroke. Unfortunately, data about language were not provided for this population [38]. 
Table 1. Studies about stroke knowledge in Spanish-speaking population without stroke

\begin{tabular}{|c|c|c|c|c|c|c|c|c|}
\hline Author/country & $\begin{array}{l}\text { Population, } \\
\mathrm{n}\end{array}$ & Selection & $\begin{array}{l}\text { Survey design } \\
\text { (close/open } \\
\text { ended) }\end{array}$ & $\begin{array}{l}\text { Educational level } \\
\text { (selementary } \\
\text { school), \% }\end{array}$ & $\begin{array}{l}\text { Knowledge of } \\
\geq \text { stroke RF, } \\
\%\end{array}$ & $\begin{array}{l}\text { Knowledge of } \\
\geq \text { stroke WS, } \\
\%\end{array}$ & $\begin{array}{l}\text { Would call } \\
\text { EMS, } \\
\%\end{array}$ & $\begin{array}{l}\text { Would go } \\
\text { to hospital, } \\
\%\end{array}$ \\
\hline Montaner/Spain & 1,000 & Health care centers & Close & 61 & - & $<50$ & 50 & 43 \\
\hline Oró/Spain & 153 & Health care centers & Close & 69.9 & - & - & 9 & 21 \\
\hline Lundelin/Spain & 11,827 & ENRICA study & Close & 30 & - & - & 81 & 4.9 \\
\hline Pérez-Lázaro/Spain & 356 & Neurological consults & Close & 51 & 49 & 55 & 60 & 39 \\
\hline Montaner/Spain & 100 & Health center & Close & - & 96 & 95 & 46 & 50 \\
\hline Góngora-Rivera/Mexico & 330 & Building complex & Open & 12.5 & 66 & 36.7 & \multicolumn{2}{|c|}{$90-$} \\
\hline Bruera/Argentina & 1,650 & Random & Open & 11.2 & - & - & 20 & - \\
\hline DuBard/USA & 527 & SSH from BFRSS & Close & - & 58 & - & 85 & - \\
\hline Goldstein/USA & 76 & Health program & Open & - & 19 & 43 & \multicolumn{2}{|c|}{-45} \\
\hline
\end{tabular}

Table 2. Knowledge of words to name stroke

\begin{tabular}{|c|c|c|c|c|c|c|c|c|c|}
\hline Author & $\begin{array}{l}\text { Population, } \\
\mathrm{n}\end{array}$ & $\begin{array}{l}\text { Ictus, } \\
\%\end{array}$ & $\begin{array}{l}\text { Embolia, } \\
\%\end{array}$ & $\begin{array}{l}\text { Trombosis, } \\
\%\end{array}$ & $\begin{array}{l}\text { Feridura*, } \\
\%\end{array}$ & $\begin{array}{l}\text { Ataque } \\
\text { cerebral, \% }\end{array}$ & $\begin{array}{l}\text { Infarto } \\
\text { cerebral, \% }\end{array}$ & $\begin{array}{l}\text { Accidente } \\
\text { cerebrovascular, \% }\end{array}$ & $\begin{array}{l}\text { Derrame } \\
\text { cerebral, \% }\end{array}$ \\
\hline Palomeras & 347 & 0 & 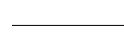 & 31.5 & - & 0 & 0 & 0 & 0 \\
\hline Segura & 3,000 & 4.5 & & & & -95. & & & \\
\hline Montaner & 1,000 & 0 & 67.5 & 17.9 & 2.6 & 5.9 & 5.7 & 0.4 & 0 \\
\hline Oró & 153 & 27.5 & 87.9 & 71.9 & 82.4 & 0 & 76.5 & 0 & 83 \\
\hline Pérez-Lázaro & 356 & 40 & & & & -60 & 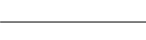 & & \\
\hline Montaner & 100 & 1 & 98.9 & 87.9 & 11 & 93.4 & 74.4 & 47.8 & - \\
\hline
\end{tabular}

* Word from Catalan.

In Spain, between 78 and $86 \%$ of individuals responded that it was the brain that was damaged the most, while the remainder responded that it was the arms or legs [26, 30] that were damaged.

\section{Knowledge of Risk Factors (RF) and Warning Signs (WS) of Stroke (Table 3)}

The most recognized RF across several populations was hypertension [26, 29-31, 39, 40]. Tobacco and alcohol were the second most recognized RF in two studies $[26,29,30]$ and stress was identified as an RF in one study [40]. Advanced age, diabetes, dyslipedemia and heart disease, on the other hand, were poorly recognized [29].

Weakness with or without sensory disturbances was the most recognized WS in eight studies [23, 26, 29, $32,37,39]$ and speech disturbances in three $[30,41]$. Interestingly, headache and unspecified pain were the first and third most frequently reported WS in Mexico and this remained unchanged after an educational campaign [40].

Hispanics in Central Harlem were likely to misclassify chest pain as a symptom of stroke compared with other populations [38]. Around $30 \%$ of individuals did so in Spain and the United States [37, 41], and approximately $5 \%$ in Mexico [39, 40]. However, in Mexico, chest pain was most frequently associated with stroke than weakness or altered sensitivity on one side of the body [40]. In Spain, $72 \%$ of respondents to a survey identified confounders as stroke symptoms.

Again SSH of the BRFSS were less likely to recognize stroke WS after adjustment for socio-demographic characteristics, healthcare access, and cardiovascular risk factors [23].

Remarkably, $11 \%$ of 76 uninsured SSH in North Carolina confounded the terms 'risk factor' and 'symp- 
Table 3. Most frequently recognized RF and WS of stroke

\begin{tabular}{|c|c|c|}
\hline Author/country & WS & $\mathrm{RF}$ \\
\hline Segura/Spain & $\begin{array}{l}\text { Weakness } \\
\text { Speech disturbances } \\
\text { Unconsciousness }\end{array}$ & $\begin{array}{l}\text { Hypertension } \\
\text { Tobacco } \\
\text { Alcohol }\end{array}$ \\
\hline Montaner/Spain & Weakness/numbness & $\begin{array}{l}\text { Hypertension } \\
\text { Alcohol } \\
\text { Tabacco }\end{array}$ \\
\hline Oró/Spain & Speech disturbances & Hypertension \\
\hline Lundelin/Spain & $\begin{array}{l}\text { Speech disturbances } \\
\text { Weakness }\end{array}$ & - \\
\hline Montaner/Spain & $\begin{array}{l}\text { Speech disturbances } \\
\text { Numbness } \\
\text { Weakness }\end{array}$ & $\begin{array}{l}\text { Hypertension } \\
\text { Alcohol } \\
\text { Tobacco }\end{array}$ \\
\hline $\begin{array}{l}\text { Pérez-Lázaro/ } \\
\text { Spain }\end{array}$ & $\begin{array}{l}\text { Weakness/numbness } \\
\text { Unconsciousness }\end{array}$ & $\begin{array}{l}\text { Hypertension } \\
\text { Dyslipemia } \\
\text { Heart disease }\end{array}$ \\
\hline $\begin{array}{l}\text { Díaz-Cabezas/ } \\
\text { Colombia }\end{array}$ & $\begin{array}{l}\text { Weakness } \\
\text { Speech disturbances }\end{array}$ & Hypertension \\
\hline $\begin{array}{l}\text { Bruera/ } \\
\text { Argentina }\end{array}$ & $\begin{array}{l}\text { Weakness/numbness } \\
\text { Confusion/Speech disturbances }\end{array}$ & - \\
\hline $\begin{array}{l}\text { Góngora-Rivera/ } \\
\text { Mexico }\end{array}$ & $\begin{array}{l}\text { Weakness } \\
\text { Headache } \\
\text { Dizziness }\end{array}$ & Hypertension \\
\hline $\begin{array}{l}\text { Gutierrez- } \\
\text { Jimenez/Mexico }\end{array}$ & $\begin{array}{l}\text { Headache } \\
\text { Speech disturbances } \\
\text { Unspecified pain }\end{array}$ & $\begin{array}{l}\text { Hypertension } \\
\text { Stress }\end{array}$ \\
\hline $\begin{array}{l}\text { DuBrad/USA } \\
\text { Ellis/USA }\end{array}$ & $\begin{array}{l}\text { Weakness } \\
\text { Weakness/numbness } \\
\text { Visual disturbances }\end{array}$ & - \\
\hline
\end{tabular}

tom', thereby suggesting barriers to comprehension of standard health education materials [42].

A combination of stroke RF and WS knowledge was used to define the 'level of stroke knowledge' in seven studies. Whether 'good stroke knowledge' was present was difficult to determine due to varying definitions (table 4).

\section{Behavior in Response to Stroke Symptoms}

Several studies reported the proportion of patients who would go to an emergency department or would call the EMS without differentiating between both decisions (table 2).

No significant differences in intention to call EMS were found comparing literacy groups among $\mathrm{SSH}$ in the United States [37].
Different actions in front of a hypothetical stroke or TIA situation were assessed in five studies. In Spain, 31 and $60.6 \%$ of patients would go to the hospital/call EMS or call their personal doctor the same day respectively, if a stroke was suspected. These percentages changed to 13.7 and $56.9 \%$ if symptoms were transient. From additional studies, it was found that $>95 \%$ of individuals would call EMS or go to the hospital in a stroke situation compared with 40,53 and $75 \%$ of TIA situations $[26,30]$. Patients with 'very good global stroke knowledge' were more likely to assign importance to TIA [26]. Lastly, in Colombia, only $11.7 \%$ of patients would present to the emergency room if stroke were suspected. This percentage improved to $92 \%$ when options were given; however, it decreased to $62 \%$ with transient symptoms [36].

No studies took into account the behavior that was expressed as a response to stroke symptoms to define 'level of stroke knowledge'. Ultimately, it may be more important to capture 'good stroke knowledge for action' combining the knowledge of WSs and intention to call EMS. This concept for potential responsiveness in a population can be tested and compared with the actual action at the onset of stroke.

\section{Treatment}

No participants knew about the existence of IV rt-PA in a Colombian study [36]. Among 1,645 Argentinian people, $40 \%$ knew that there was a specific treatment for stroke, and only $24 \%$ knew that it was time-sensitive [32]. Interestingly, $86 \%$ of $76 \mathrm{SSH}$ in the United States responded that stroke could be treated despite their poor stroke knowledge. However, this study did not explore IV rt-PA or the therapeutic window time knowledge [42]. Whether or not knowing about IV rt-PA availability would have a public health impact is unknown because it is not available to treat stroke in many regions of South America [43, 44]. In Argentina, for example, IV rt-PA was administered only to $1.2 \%$ of patients in private hospitals [44]. It is not known to what degree this is influenced by the availability of neurologists.

\section{Information Source for Gaining Stroke Knowledge}

Physicians and relatives are the most frequently cited information sources. Mass media seem to be important too (table 5). In Colombia, $10.2 \%$ of patients had not received any information regarding stroke [36]. This percentage was much higher in Mexico, where $83 \%$ had not received any information. Among the latter, those who had received information made fewer mistakes in their answers about stroke knowledge [39]. 
Table 4. Definitions of 'level of stroke knowledge'

\begin{tabular}{|c|c|c|c|}
\hline Author/country & Level & Definition & Achievement, \% \\
\hline \multirow[t]{3}{*}{ Oró/Spain } & Good & $>3 \mathrm{WS} / \mathrm{RF}$ and $<2$ distractors & - \\
\hline & Optimum & $>4 \mathrm{RF} / \mathrm{WS}$ and $\leq 1$ distractor & $31 / 40$ \\
\hline & Minimum & Recognition of motor and speaking impairment & 57 \\
\hline Segura/Spain & Suitable & $\begin{array}{l}\text { Advanced age/hypertension as RF and } \\
\text { weakness-speech disturbances/vision loss as WS }\end{array}$ & 10.5 \\
\hline Lundelin/Spain & Adequate & $4-6 \mathrm{WS}$ & 65.2 \\
\hline \multirow[t]{3}{*}{ Montaner/Spain } & Good (RFs) & Recognition of $\geq 5$ and $\leq 1$ error & 37 \\
\hline & Good (WSs) & $\geq 3$ and $\leq 1$ mistake & 50 \\
\hline & Very good & Good knowledge of WS and RF & 20 \\
\hline \multirow[t]{3}{*}{$\begin{array}{l}\text { Díaz-Cabezas/ } \\
\text { Colombia }\end{array}$} & $\mathrm{Bad}$ & $\begin{array}{l}* \text { No correct answers/ } \\
* * 1 \text { correct option and } \geq 2 \text { distractors }\end{array}$ & \multirow{2}{*}{$\mathrm{RF}^{*} 50 / * * 39 \mathrm{WS} * 94 / * * 60$} \\
\hline & Regular & $\begin{array}{l}* \geq 2 \text { correct answers/ } \\
* * 2 \text { correct options and } 2 \text { distractors }\end{array}$ & \\
\hline & Good & $* 1 /{ }^{* *} \geq 3$ correct options and 1 distractor & $\mathrm{RF}^{*} 50 / * * 61 \mathrm{WS}^{*} 6 / * * 40$ \\
\hline \multirow[t]{2}{*}{$\begin{array}{l}\text { Pérez-Lázaro/ } \\
\text { Spain }\end{array}$} & Good & $\begin{array}{l}\text { **4 RF no distractors } \\
* * 3 \text { WS no distractors }\end{array}$ & $\begin{array}{l}30 \\
56\end{array}$ \\
\hline & Very good & $\begin{array}{l}*>1 \mathrm{WS} \\
*>1 \mathrm{RF}\end{array}$ & $\begin{array}{l}29 \\
26\end{array}$ \\
\hline \multirow[t]{2}{*}{ Montaner/Spain } & Good & $\begin{array}{l}\geq 3 \mathrm{WS} \leq 1 \text { mistake } \\
\geq 3 \mathrm{RF} \leq 1 \text { mistake }\end{array}$ & $\begin{array}{l}42 \\
46\end{array}$ \\
\hline & Very good & Good knowledge of RF and WS & 22 \\
\hline
\end{tabular}

* Spontaneous answers. ** Answers after recognition from a list.

Table 5. Information sources for gaining stroke knowledge

\begin{tabular}{lllllll}
\hline Author/country & $\begin{array}{l}\text { Physicians, } \\
\%\end{array}$ & $\begin{array}{l}\text { Nurses/health } \\
\text { care system, } \%\end{array}$ & $\begin{array}{l}\text { Relatives, } \\
\%\end{array}$ & $\begin{array}{l}\text { Internet, } \\
\%\end{array}$ & $\begin{array}{l}\text { Television/ } \\
\text { newspapers/ } \\
\text { radio/books, \% }\end{array}$ & $\begin{array}{l}\text { School/ } \\
\text { institutes, } \\
\%\end{array}$ \\
\hline Oró/Spain & 43.8 & 7.8 & 32.7 & 11.1 & 24.2 & 3.9 \\
Diez/Spain & 64 & - & 33 & 16 & 13 & - \\
Montaner/Spain & - & - & 50 & - & - & - \\
Díaz-Cabezas/Colombia & 23 & 12.2 & 31.2 & - & 23 & - \\
Góngora-Rivera/Mexico & 10 & - & - & - & 7.3 & - \\
\hline
\end{tabular}

\section{Educational Interventions}

Educational campaigns in Latin America are limited. One educational campaign conducted by previously trained medical students through conferences and printed material was done for 6 months among randomly selected habitants of a multifamily housing unit in Mexico.
After the successful conduct of this campaign, recognition of obesity, lipid disorders, and drug use as RF and hemiparesis as WS improved [40].

In Argentina, recognition of RF and WS through behavior against stroke and treatment knowledge improved after a multimodal campaign conducted by previously 
trained medical students among randomly selected people. However, $60 \%$ of individuals thought that stroke is an infrequent illness before and after educational intervention [32].

\section{Stroke Knowledge in Patients Evaluated after Stroke}

Six studies evaluated stroke knowledge from 'what patients did when they had a stroke'.

\section{Knowledge Regarding Cause of Symptoms}

Awareness of having a stroke and emergency perception of stroke symptoms were associated with shorter arrival times $[28,33,45]$.

Between 27 and $43 \%$ of stroke patients correctly interpreted their symptoms as consistent with stroke in different studies [25, 33, 45-47].

Stroke severity, motor symptoms, speech disturbances and prior stroke/TIA have been related with correct symptom interpretation [45-47]. The latter association was not found in Argentina and Spain [33, 46]. For example, in Spain, $76.2 \%$ of patients with recurrent stroke did not recognize new events after the first one [46]. Interestingly, in the same studies, educational level was not related with correct stroke symptoms recognition [33, 46].

\section{Behavior in Response to Stroke Symptoms}

In Madrid, Spain, 56\% of the surveyed went directly to the emergency department, although only $27 \%$ recognized their symptoms as stroke. The remaining stayed at home or attended to primary care physician [46]. In Meresme (county with rural areas), Spain, $31.8 \%$ of individuals went immediately to the hospital or called an ambulance. Others waited for symptoms to improve (21.9\%) or called their primary care doctor or pharmacy $(21.2 \%)$ [28].

In another study from Spain, $60 \%$ of individuals arrived before $3 \mathrm{~h}$ of symptom onset. However, ambulance delay was experienced by $15 \%$ of 247 patients who arrived at the hospital after the first hour [47]. Additional data from the same country suggest that not contacting a primary care physician as first action in acute stroke have been related with arrival in first $3 \mathrm{~h}$ [45].

Mexican Americans in the United States were less likely to use the EMS compared with non-Hispanics whites. However, no association with language and time to presentation or mode of arrival was found [25]. This may
Table 6. Neurologist per 100,000 population (WHO)

\begin{tabular}{llll}
\hline \multicolumn{2}{l}{ Neurologist per 100,000 population } \\
\hline$>5$ & $1.1-5$ & $0.11-1$ & no data \\
\hline USA & Spain & Mexico & Chile \\
& Canada & Venezuela & Bolivia \\
& Brazil & Ecuador & Peru \\
& Argentina & & Paraguay \\
& Colombia & & \\
& Uruguay & & \\
\hline
\end{tabular}

suggest a cultural or economic rather than a language barrier to EMS activation.

In Latin America, data is available only from Argentina. In one study, only $36 \%$ of individuals called EMS without arrival times getting better [33].

\section{Patients' Beliefs}

Two studies explored patients' beliefs about stroke. In a Spanish population, $60 \%$ thought that religion helped them to recover after a stroke. Up to half of the patients could explain the biological mechanisms of the illness and thought that an emotional stressor was the cause the stroke [46].

Mexican-Americans in the United States reported distrust in the medical establishment and expressed concern that financial considerations impeded their seeking medical care. These beliefs may prevent people from calling the EMS [25].

\section{Stroke Knowledge among Providers}

According to WHO data, $50 \%$ of countries in America responding to a survey have less than 1 neurologist per 100,000 population. No data were available on Chile, Bolivia, Peru, Paraguay and other countries in Central America (table 6) [48].

Misdiagnosis of stroke is common in the emergency room and by primary care physicians [49]. The presence of a neurologist available in the ER could solve this difficulty [50].

We found limited data regarding the misdiagnosis of stroke in Spanish-speaking countries. However, indirect findings suggest that misdiagnosis may interfere with initial stroke workup and hence thrombolysis in SSP $[6,33$, $45,51]$.

In Argentina, 14 out of 41 (36\%) patients who arrived in the first 6 hours of stroke symptoms had a diagnostic 
delay, losing an opportunity of potential treatment. The principal cause was misdiagnosis, with a non-neurologist being the initial provider $95 \%$ of the time [33].

Also, in Argentina, 596 physicians working in an emergency department were evaluated about pre-hospital stroke scales as an instrument to screen for stroke notifications. Only 32\% knew about Cincinnati (CPSS) and Los Angeles Scales (LAPSS), and only $8.4 \%$ could tell all points of CPSS, $1.9 \%$ the LAPSS and $0.7 \%$ both. Nonetheless, $89 \%$ of the surveyed physicians found the scales useful to evaluate stroke patients in the emergency room. Interestingly, those who remembered the scales felt more secure to evaluate a patient with possible stroke [51].

In Andalucía, Spain, $46.4 \%$ of emergency physicians failed the first stage exam of an educational program of stroke knowledge. Worst scores were found in knowledge of neurological impairment, dosages for antihypertensive drugs and IV rt-PA, physiological neuroprotection, early signs of stroke, and contraindications for thrombolysis. After training, knowledge improved and the use of IV rt-PA increased by $4.5 \%$ over 3 years [6].

\section{Conclusions}

SSP are heterogeneous regarding cultural backgrounds, racial and ethnical origins, economic status and sophistication of health care systems. Studies examining stroke knowledge in Spanish-speaking countries are lacking, particularly in Latin America. In the few studies published, stroke knowledge is poor among potential stroke sufferers, stroke survivors, and providers. These findings may occur due to on the inconsistent use of the word that indicated stroke in Spanish, inconsistent utilization of IV rt-PA in several Latin American countries, and overall poor access to medical care and neurologists in particular. It is necessary to make greater efforts mainly in Latin American population to know more about stroke in general population but mainly in high risk population and particularly related to risk factors, warning signs and quick call to EMS associated with a shorter arrival time to hospital.

Recognition and conduct when symptoms are transient is a topic of concern and little is known among Spanish speakers. This point deserves special attention to further educational programs. New epidemiological studies from Latin American countries describing the current state of stroke knowledge are needed, particularly since data from the United States and Spain may not be generalizable. Further understanding of the baseline knowledge and gaps in these countries can then allow for future studies examining educational campaigns, which are culturally tailored to each individual country and population for potential patients, families, the public and providers. These interventions will need to consider using a consistent term for stroke in Spanish (including in the medical literature), and include personal physicians and relatives since they are often the most reported information sources by patients. Partnerships between government agencies, nonprofit organizations, medical institutions and mass media outlets akin to efforts in the United States will be necessary, particularly to make them specific to the cultures of each country and region. Lastly, education will likely need to be expanded in parallel early on in the instruction of medical students in Latin America to improve stroke knowledge among providers.

Unlike many regions in Europe, the lack of neurologists in some countries and their concentration in large metropolitan centers may be an important gap to solve in the coming years. Programs to train general practitioners in stroke and telemedicine present one possible solution to improve access in under-served areas similar to successfully implemented program in the United States.

\section{Disclosure Statement}

M.A. Hawkes and S.F. Ameriso: none declared. J.Z. Willey: funded by NIH/NINDS K23.

\section{Appendix 1}

Lilacs: $[29,39,41,45]$.

Scielo: [35].

Scopus: [42].

PubMed: [23, 25-29, 37, 41, 42, 52].

\section{Appendix 2}

Search strategy: ('stroke awareness' OR 'stroke literacy' OR 'stroke knowledge' OR 'stroke recognition' OR 'stroke symptoms' OR 'stroke preparedness' OR 'stroke perception' OR 'ictus knowledge') AND ('Hispanic' OR 'Latin' OR 'Spanish speaking' OR 'Spanish' OR 'Spain' OR 'Latin America' OR 'South America' OR 'Central America' OR 'America' OR 'Hispanos' OR 'Latinos' OR 'España’ OR 'Español'). 


\section{References}

1 Feigin VL, Forouzanfar MH, Krishnamurthi R, Mensah GA, Connor M, Bennett DA, Moran AE, Sacco RL, Anderson L, Truelsen T, O’Donnell M, Venketasubramanian N, Barker-Collo S, Lawes CM, Wang W, Shinohara Y, Witt E, Ezzati M, Naghavi M, Murray C: Global and regional burden of stroke during 1990 2010: findings from the global burden of disease study 2010. Lancet 2014;383:245-254.

2 Murray CJ, Lopez AD: Measuring the global
burden of disease. N Engl J Med 2013;369: burden

-3 Tissue plasminogen activator for acute ischemic stroke. The National Institute of Neurological Disorders and Stroke rt-PA Stroke Study Group. N Engl J Med 1995;333:15811587.

4 Hacke W, Kaste M, Bluhmki E, Brozman M, Davalos A, Guidetti D, Larrue V, Lees KR, Medeghri Z, Machnig T, Schneider D, von Kummer R, Wahlgren N, Toni D: Thrombolysis with alteplase 3 to 4.5 hours after acute ischemic stroke. N Engl J Med 2008;359: 1317-1329.

5 Nasr DM, Brinjikji W, Cloft HJ, Rabinstein AA: Utilization of intravenous thrombolysis is increasing in the United States. Int J Stroke 2013;8:681-688.

6 Navarrete-Navarro P, Murillo-Cabeza F, Bono-de-Seras R, Rodriguez-Romero R, Rodriguez-Zarallo A, Vazquez-Mata G: Development of an acute ischemic stroke management course for hospital physicians in emergency departments and intensive care units. Eur J Emerg Med 2012;19:108-111.

$\checkmark 7$ Rosamond WD, Gorton RA, Hinn AR, Hohenhaus SM, Morris DL: Rapid response to stroke symptoms: the delay in accessing stroke healthcare (DASH) study. Acad Emerg Med 1998;5:45-51.

-8 Feldmann E, Gordon N, Brooks JM, Brass LM, Fayad PB, Sawaya KL, Nazareno F, Levine SR: Factors associated with early presentation of acute stroke. Stroke 1993;24: 1805-1810.

9 Williams LS, Bruno A, Rouch D, Marriott DJ: Stroke patients' knowledge of stroke. Influence on time to presentation. Stroke 1997;28: 912-915.

10 Wester P, Radberg J, Lundgren B, Peltonen M: Factors associated with delayed admission to hospital and in-hospital delays in acute stroke and TIA: a prospective multicenter study. Seek-medical-attention-in-time study group. Stroke 1999;30:40-48.

11 Clark JM, Renier SA: A community stroke study: factors influencing stroke awareness and hospital arrival time. J Stroke Cerebrovasc Dis 2001;10:274-278.

12 Schroeder EB, Rosamond WD, Morris DL, Evenson KR, Hinn AR: Determinants of use of emergency medical services in a population with stroke symptoms: the second delay in accessing stroke healthcare (DASH II) study. Stroke 2000;31:2591-2596.
13 Kothari R, Sauerbeck L, Jauch E, Broderick J, Brott T, Khoury J, Liu T: Patients' awareness of stroke signs, symptoms, and risk factors. Stroke 1997;28:1871-1875.

14 Centers for Disease Control and Prevention (CDC): Awareness of stroke warning symptoms - 13 states and the district of Columbia, 2005. MMWR Morb Mortal Wkly Rep 2008; 57:481-485.

15 Miyamatsu N, Okamura T, Nakayama H, Toyoda K, Suzuki K, Toyota A, Hata T, Hozawa A, Nishikawa T, Morimoto A, Ogita M, Morino A, Yamaguchi T: Public awareness of early symptoms of stroke and information sources about stroke among the general Japanese population: the acquisition of stroke knowledge study. Cerebrovasc Dis 2013;35:241-249.

16 Ellis C, Barley J, Grubaugh A: Poststroke knowledge and symptom awareness: a global issue for secondary stroke prevention. Cerebrovasc Dis 2013;35:572-581.

17 List of languages by number of native speakers, 2014.

18 Paul LM, Simons GF, Fennig CD (eds): Ethnologue: Languages of the World. Dallas, Texas, SIL International, 2014, 2015.

19 Lutfiyya MN, Bardales R, Bales R, Aguero C, Brady S, Tobar A, McGrath C, Zaiser J, Lipsky MS: Awareness of heart attack and stroke symptoms among Hispanic male adults living in the United States. J Immigr Minor Health 2010;12:761-768.

20 Romano JG, Sacco RL: Quantifying and addressing persistent stroke disparities in Hispanics. Ann Neurol 2013;74:759-761.

21 Cruz-Flores S, Rabinstein A, Biller J, Elkind MS, Griffith P, Gorelick PB, Howard G, Leira EC, Morgenstern LB, Ovbiagele B, Peterson E, Rosamond W, Trimble B, Valderrama AL; American Heart Association Stroke Council, Council on Cardiovascular Nursing, Council on Epidemiology and Prevention, Council on Quality of Care and Outcomes Research: Racial-ethnic disparities in stroke care: the American experience: a statement for healthcare professionals from the American heart association/American stroke association. Stroke 2011;42:2091-2116.

-22 Nasr DM, Brinjikji W, Cloft HJ, Rabinstein AA: Racial and ethnic disparities in the use of intravenous recombinant tissue plasminogen activator and outcomes for acute ischemic stroke. J Stroke Cerebrovasc Dis 2013;22:154-160.

23 DuBard CA, Garrett J, Gizlice Z: Effect of language on heart attack and stroke awareness among U.S. Hispanics. Am J Prev Med 2006; 30:189-196.

24 Ferris A, Robertson RM, Fabunmi R, Mosca L; American Heart Association; American Stroke Association: American heart association and American stroke association national survey of stroke risk awareness among women. Circulation 2005;111:1321-1326.

25 Smith MA, Lisabeth LD, Bonikowski F, Morgenstern LB: The role of ethnicity, sex, and language on delay to hospital arrival for acute ischemic stroke. Stroke 2010;41:905-909.

-26 Montaner J, Vidal C, Molina C, Alvarez-Sabin $\mathrm{J}$ : Selecting the target and the message for a stroke public education campaign: a local survey conducted by neurologists. Eur J Epidemiol 2001;17:581-586.

27 Oró M, Sanahuja-Montesinos J, Hernández L, Setó E, Purroy F: [The extent of knowledge about strokes among the population of a rural area in the province of Lleida]. Rev Neurol 2009;48:515-519.

28 Palomeras E, Fossas P, Quintana M, Monteis R, Sebastián M, Fábregas C, Ciurana A, Ribó M, Cano A, Sanz P, Floriach M, Alvarez-Sabín $\mathrm{J}$ : Emergency perception and other variables associated with extra-hospital delay in stroke patients in the maresme region (Spain). Eur J Neurol 2008;15:329-335.

29 Segura T, Vega G, López S, Rubio F, Castillo $\mathrm{J}$ : Public perception of stroke in Spain. Cerebrovasc Dis 2003;16:21-26.

30 Montaner J, Mauleón A, Vidal a C, Molina C, Alvarez-Sabín J: [Stroke: a stranger among the people]. Rev Neurol 1998;27:943-947.

31 Pérez-Lázaro C, Iñíguez-Martínez C, SantosLasaosa S, Alberti-González O, MartínezMartínez L, Tejero-Juste C, MostaceroMiguel E: [Study into what the population knows about strokes and vascular risk factors]. Rev Neurol 2009; 49:113-118.

32 Bruera G, Arca A, Sposato L, Ameriso SF, Zurru MC: Día mundial del ataque cerebral en Argentina: evaluación del impacto educacional en una población. Neurol Argent 2010;P44.119.

33 Hawkes M, Calandri I, Farez M, Arena J, Pujol Lereis V, Ameriso A: Perception of stroke symptoms and utilization of emergency medical systems in Argentina (P7.132). Neurology 2014;82:6-12.

34 Lavallée PC, Meseguer E, Abboud H, Cabrejo L, Olivot JM, Simon O, Mazighi M, Nifle C, Niclot P, Lapergue B, Klein IF, Brochet E, Steg PG, Lesèche G, Labreuche J, Touboul PJ, Amarenco P: A transient ischaemic attack clinic with round-the-clock access (SOS-TIA): feasibility and effects. Lancet Neurol 2007;6: 953-960.

35 Doldán L, Fernández-Suárez M, Hawkes $M$, Pujol Lereis V, Povedano GP, Ameriso SF: Diagnóstico y manejo temprano del accidente isquémico transitorio. Neurol Argent 2011; P4.10.

36 Díaz Cabezas R, Ruano Restrepo MI: Knowledge of symptoms and risk factors for stroke in an urban population in Colombia. Acta Neurol Colomb 2011;27:195-204.

37 Ellis C, Wolff J, Wyse A: Stroke awareness among low literacy Latinos living in the South Carolina low country. J Immigr Minor Health 2009;11:499-504.

38 Willey JZ, Williams O, Boden-Albala B: Stroke literacy in Central Harlem: a high-risk stroke population. Neurology 2009;73:1950-1956. 
39 Góngora-Rivera F, Gutiérrez-Jiménez E, Zenteno MA; GEPEVC Investigators: Knowledge of ischemic stroke among a Mexico city population. J Stroke Cerebrovasc Dis 2009; 18: 208-213.

40 Gutiérrez-Jiménez E, Góngora-Rivera F, Martínez HR, Escamilla-Garza JM, Villarreal HJ; GECEN Investigators: Knowledge of ischemic stroke risk factors and warning signs after a health education program by medical students. Stroke 2011;42:897-901.

41 Lundelin K, Graciani A, García-Puig J, GuallarCastillón P, Taboada JM, Rodríguez-Artalejo $\mathrm{F}$, Banegas JR: Knowledge of stroke warning symptoms and intended action in response to stroke in Spain: a nationwide population-based study. Cerebrovasc Dis 2012;34:161-168.

42 Goldstein LB, Silberberg M, McMiller Y, Yaggy SD: Stroke-related knowledge among uninsured Latino immigrants in Durham county, North Carolina. J Stroke Cerebrovasc Dis 2009; 18:229-231.

43 Pontes-Neto OM, Silva GS, Feitosa MR, de Figueiredo NL, Fiorot JA Jr, Rocha TN, Massaro AR, Leite JP: Stroke awareness in Brazil: alarming results in a community-based study. Stroke 2008;39:292-296.

44 Atallah AM, Fustinoni O, Zurru MC, Beigelman R, Cirio J, S.F. A, Burry G: Identifying barriers in acute stroke therapy in Argentina. ARENAS registry (P2.014). Neurology 2014; 82:P2.014.

45 Geffner D, Soriano C, Pérez T, Vilar C, Rodríguez $\mathrm{D}$ : Delay in seeking treatment by patients with stroke: who decides, where they go, and how long it takes. Clin Neurol Neurosurg 2012;114:21-25.

46 Díez-Ascaso O, Martinez-Sánchez P, Fuentes B, Díez-Tejedor E: Sociocultural study on the self-perception of stroke and an analysis of doctor-patient communication. Neurologia 2011;26:81-91.

47 Palomeras Soler E, Fossas Felip P, Quintana Luque M, Monteis Cahis R, Sebastián Salvatierra M, Fábregas Casarramona C, Ciurana Ortells A, Cano Orqaz AT, Sanz Cartagena P, Floriach Robert M, Alvarez Sabin J: [Knowledge about stroke symptoms and attitude towards them in the population]. Neurologia 2007;22:434-440.
48 Atlas: Country Resources for Neurological Disorders; Geneva, World Health Organization and World Federation of Neurology, 2004, pp 28-29.

49 Harbison J, Hossain O, Jenkinson D, Davis J, Louw SJ, Ford GA: Diagnostic accuracy of stroke referrals from primary care, emergency room physicians, and ambulance staff using the face arm speech test. Stroke 2002;34:7176.

50 Moulin T, Sablot D, Vidry E, Belahsen F, Berger E, Lemounaud P, Tatu L, Vuillier F, Cosson A, Revenco E, Capellier G, Rumbach L: Impact of emergency room neurologists on patient management and outcome. Eur Neurol 2003;50:207-214.

51 García-Zamora S, Elías R, Schipper NP, Palameta F, Parodi R, Gallo R, Greca A: Conocimiento de escalas de evaluación inicial de accidente cerebrovascular por médicos de guardia en tres provincias argentinas. Revista Medica de Rosario Rosario 2013;79:62-72.

52 Ellis C, Egede LE: Ethnic disparities in stroke recognition in individuals with prior stroke. Public Health Rep 2008;123:514-522. 